\title{
Syringocystadenoma papilliferum in the right lower abdomen: a case report and review of literature
}

This article was published in the following Dove Press journal:

OncoTargets and Therapy

25 March 2013

Number of times this article has been viewed

\author{
Dong $\mathrm{Xu}^{1,2}$ \\ Tienan $\mathrm{Bi}^{3,2}$ \\ Huanrong $\operatorname{Lan}^{3,2}$ \\ Wenjie Yu' \\ Wenmin Wang' \\ Feilin $\mathrm{Cao}^{1,2}$ \\ Ketao Jin ${ }^{1,2}$ \\ 'Department of Surgical Oncology, \\ Taizhou Hospital, Wenzhou Medical \\ University, Linhai, Zhejiang, People's \\ Republic of China; ${ }^{2}$ Laboratory \\ of Translational Oncology, Public \\ Research Platform, Taizhou Hospital, \\ Wenzhou Medical University, Linhai, \\ Zhejiang, People's Republic of China; \\ ${ }^{3}$ Department of Gastrointestinal \\ Surgery, Taizhou Hospital, Wenzhou \\ Medical University, Linhai, Zhejiang, \\ People's Republic of China
}

\begin{abstract}
Syringocystadenoma papilliferum (SCAP) is an uncommon benign adnexal tumor of the skin. It is frequently seen in association with other benign adnexal lesions, such as nevus sebaceous, apocrine nevus, tubular apocrine adenoma, apocrine hidrocystoma, apocrine cystadenoma, and clear cell syringoma. The unusual reported locations of SCAP include the head and neck, the buttock, the vulva, the scrotum, the pinna, the eyelid, the outer ear canal, the forehead, the back, the scalp, the thigh, the nipple, the axilla, and the postoperative scar. The occurrence of SCAP in the right lower abdomen is distinctly uncommon. Herein, we report an unusual case of a 41-year-old man with SCAP occurring in the right lower abdomen that did not develop malignancy, despite a long disease course and an absence of medical treatment. The clinical and histopathologic features and the differential diagnosis of SCAP are also discussed.
\end{abstract}

Keywords: adnexal, skin tumor, benign

\section{Introduction}

Syringocystadenoma papilliferum (SCAP) is a rare, benign adnexal tumor that, in 50\% of cases, is present at birth or in early childhood, while in another $15 \%-30 \%$ of cases, develops during puberty. ${ }^{1,2}$ Although benign, its transition to basal cell carcinoma, metastatic adenocarcinoma, and ductal carcinoma may occur., ${ }^{3,4}$ SCAP often occurs in association with other benign adnexal lesions, such as nevus sebaceous, ${ }^{5}$ apocrine nevus, ${ }^{6}$ tubular apocrine adenoma,${ }^{7,8}$ apocrine hidrocystoma, apocrine cystadenoma, ${ }^{9}$ and clear cell syringoma. ${ }^{10}$

According to Shams et al, ${ }^{11}$ there have been 261 reported cases. Roughly $50 \%$

Correspondence: Feilin Cao Department of Surgical Oncology and Laboratory of Translational Oncology, Public Research Platform, Taizhou Hospital, Wenzhou Medical University, I50, Ximen Road, Linhai, Zhejiang 317000, People's Republic of China

Tel +8657685199051

Fax +8657685199876

Email dr.caofeilin@yahoo.com.cn

Ketao Jin

Department of Surgical Oncology and Laboratory of Translational Oncology, Public Research Platform, Taizhou Hospital, Wenzhou Medical University, I50, Ximen Road, Linhai, Zhejiang 317000, People's Republic of China $\mathrm{Tel}+865768519905$ I

Fax +8657685199876

Email jinketao200।@yahoo.com.cn present at birth or in early childhood. ${ }^{11}$ Most often, SCAP is asymptomatic. It can have a variable clinical presentation, appearing as a solitary papule or a linear arrangement of several papules. With increasing size, a more prominent papillary configuration develops, and the surface can become scabbed. Macroscopically, the mature lesion consists of clusters of generally pinkish-brown nodules, $2-10 \mathrm{~mm}$ in diameter, with an occasional central opening. During puberty, SCAP may increase in size and develop a crusted and papillomatous texture. ${ }^{12}$ The most common location is the head and neck, ${ }^{13-15}$ and it is really rare to see SCAP located in the abdomen. We report here a fourth case of SCAP in the right lower abdomen that did not develop malignancy, despite a long disease course and an absence of medical treatment.

\section{Case report}

A 41-year-old man was referred to the Department of Surgical Oncology, Taizhou Hospital (Linhai, People's Republic of China) in November 2012, with a giant sessile, 
moist, pinkish tumor located in the right lower abdomen. He reported having a small elevated nodular swelling in the right lower abdomen for the past three decades. The patient reported that during this time, the tumor had slowly, but consistently, increased in size and over the past 2 years had become more noticeable, combined with painful itching and bleeding on touching. In November 2012, the patient finally sought treatment because of local pain and bleeding from the tumor. Physical examination revealed a giant $4.0 \times 2.0 \mathrm{~cm}$ brownish, verrucous tumor (Figure 1). The tumor surface was a moist, pinkish mass with a few hemorrhagic areas. Though the clinical suspicion was either a squamous cell or a basal cell carcinoma, the initial pathologic diagnosis of a small wedge biopsy specimen was SCAP, with no evidence of malignancy. The mass was excised along with a $3 \mathrm{~mm}$ margin of healthy skin. The final pathologic diagnosis of the excised specimen confirmed the initial report.

Histopathologically, the tumor was characterized by a number of cystic invaginations extending downwards from the epidermis (Figure 2A and B). Numerous papillary projections extended into the lumen of these invaginations. The papillary projections were lined with a two-layer epithelium comprising an inner cylindrical and an outer cuboidal layer. A dense dermal cellular infiltrate, consisting primarily of plasma cells and lymphocytes, was prominent in the papillary projections. The histological findings were consistent with a verrucous form of SCAP (Figure 2A and B).

\section{Discussion}

SCAP is an uncommon skin adnexal tumor of sweat gland origin that usually occurs as a solitary lesion. Although most

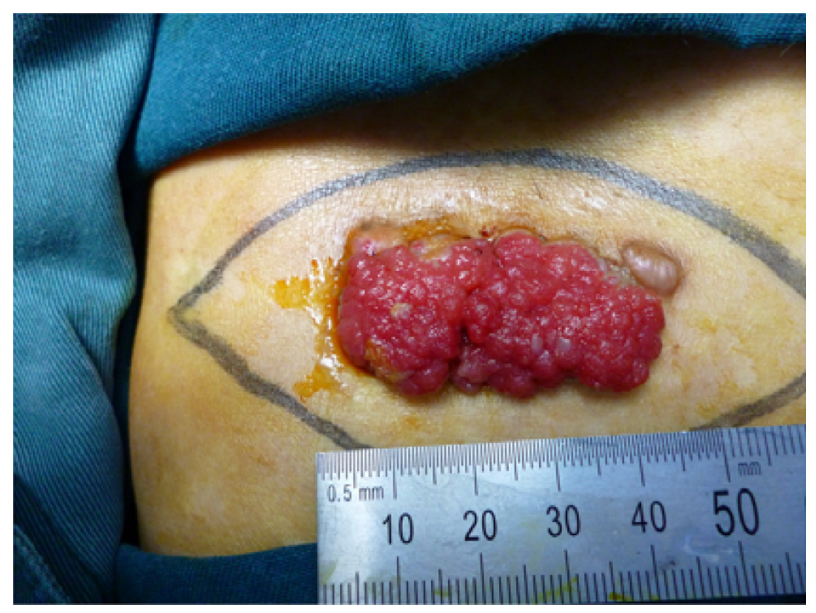

Figure I Clinical appearance before surgery.

Notes: The photograph shows a large, sessile, moist, pinkish mass with a few hemorrhagic areas in the right lower abdomen.

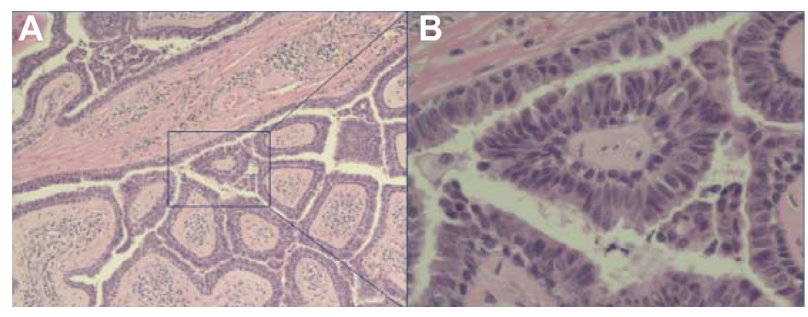

Figure 2 (A) Low power view showing a double-layered epithelial lining comprised of tubular structures, with dense plasma cells and lymphocyte infiltrate in the stroma (original magnification $\times 100$ ); (B) High power view showing a double layer of epithelium lining the papillary surfaces, with a columnar layer on the luminal side and a cuboidal layer on the other (original magnification $\times 400$ ).

Note: Hematoxylin and eosin staining.

lesions are not clinically distinctive and require biopsy for diagnosis, the tumor is usually described as a skin-colored to pink, hairless, firm plaque of grouped nodules or as a solitary nodule, but verrucous, papillary, hyperkeratotic, moist, fleshy excrescences have also been described. Some tumors may show central umblication, through which small fistulae may discharge fluid.

The great majority of SCAP arise on the head and neck. ${ }^{13}$ Other unusual reported locations of SCAP include the buttock, ${ }^{16}$ vulva and scrotum, ${ }^{17,18}$ pinna, ${ }^{19}$ eyelid, ${ }^{20-22}$ outer ear canal, ${ }^{23}$ postoperative scar, ${ }^{24}$ scalp,${ }^{25}$ nipple, ${ }^{26}$ thigh, ${ }^{27}$ axilla, ${ }^{28}$ and back, ${ }^{29}$ but only three cases in the right lower abdomen were previously reported..$^{30-32}$ To our knowledge, this is the fourth case reported. Most of the lesions develop and enlarge gradually, although a few can attain considerable size within a few months. Clinically, SCAP presents with a range of nonspecific lesions. Diagnosis may be confirmed by histopathology. One study reported that ultrastructurally, although there were some variations in the electron density of the cells, the constituent epithelial cells were mainly divided into three types: luminal cells, basal cells, and clear cells. ${ }^{33}$

The differential diagnosis of SCAP includes hidradenoma papilliferum, papillary eccrine adenomas, warty dyskeratoma, and inverted follicular keratosis. Clinically, SCAP presents as raised warty plaques on the head and neck, often in the setting of nevus sebaceus. Ducts invaginate from the surface into the dermis. Papillary fronds extend upward from the base, while plasma cells are common in the core of each frond. ${ }^{9}$ Hidradenoma papilliferum similarly differentiates towards the secretory portion of the sweat gland but is more common on the vulva, breast, or eyelid, and unlike SCAP, there is no epidermal connection with hidradenoma papilliferum (it "hides" in the dermis). The dermal nodule of hidradenoma papilliferum consists of ducts that are arborized in a mazelike pattern, without plasma cell cores. Papillary eccrine adenomas are composed of multiple, dermal, dilated, 
duct-like spaces containing papillary projections. Similar to SCAP, warty dyskeratoma and inverted follicular keratosis show an endophytic pattern. However, warty dyskeratomas are lined by elongated dermal papillae with suprabasilar acantholysis of keratinocytes, some of which are dyskeratotic, and inverted follicular keratosis resembles an expanded hair follicle, with squamous eddies (whorls of mature squamous epithelium).

The histogenesis of SCAP is uncertain. Whether SCAP is derived from apocrine or eccrine glands is undetermined. ${ }^{11,34}$ Immunohistochemical studies conducted by Mazoujian and Margolis ${ }^{35}$ support an apocrine origin, whereas ultrastructural analysis favors an eccrine derivation. ${ }^{36}$ Alternatively, it has been speculated that SCAP might arise from pluripotent stem cells. ${ }^{33}$ This would support a mix of apocrine and eccrine elements.

Cases of SCAP are limited. The only treatment for SCAP is excision biopsy, which also confirms the diagnosis. $\mathrm{CO}_{2}$ laser excision of SCAP of the head and neck is a clinical treatment option in anatomic areas that are unfavorable for excision and grafting. ${ }^{37}$ SCAP has also been successfully treated with Mohs micrographic surgery. ${ }^{38}$

In conclusion, SCAP is an uncommon sweat gland tumor with a widely variable clinical appearance. The peculiarity of our case lies in the rarity of SCAP and its location in the right lower abdomen. We believe that the present case is the fourth report of SCAP in the right lower abdomen. Our case represents an unusual presentation of an uncommon tumor at a rare location, with significant impairment in quality of life that improved after surgical excision.

\section{Acknowledgments}

This work was supported by Zhejiang Provincial Medical and Healthy Science and Technology Projects (Grants No 2011KYB137), the Science Research Fund of Taizhou (Grants No A102KY09 and A121KY08), and the Enze Medical Research Fund (Grants No 12EZA1).

\section{Disclosure}

The authors report no conflicts of interest in this work.

\section{References}

1. Böni R, Xin H, Hohl D, Panizzon R, Burg G. Syringocystadenoma papilliferum: a study of potential tumor suppressor genes. $A m J$ Dermatopathol. 2001;23(2):87-89.

2. Karg E, Korom I, Varga E, Ban G, Turi S. Congenital syringocystadenoma papilliferum. Pediatr Dermatol. 2008;25(1):132-133.

3. Arai Y, Kusakabe H, Kiyokane K. A case of syringocystadenocarcinoma papilliferum in situ occurring partially in syringocystadenoma papilliferum. J Dermatol. 2003;30(2):146-150.
4. Diaz RC, Babu SC. Ductal carcinoma arising from syringocystadenoma papilliferum in the external auditory canal. Otol Neurotol. 2007;28(6):873-874.

5. Mammino JJ, Vidmar DA. Syringocystadenoma papilliferum. Int $J$ Dermatol. 1991;30(11):763-766.

6. Misago N, Narisawa Y. Syringocystadenoma papilliferum with extensive apocrine nevus. J Dermatol. 2006;33(4):303-305.

7. Lee CK, Jang KT, Cho YS. Tubular apocrine adenoma with syringocystadenoma papilliferum arising from the external auditory canal. J Laryngol Otol. 2005;119(12):1004-1006.

8. Yamane N, Kato N, Yanagi T, Osawa R. Naevus sebaceus on the female breast accompanied with a tubular apocrine adenoma and a syringocystadenoma papilliferum. Br J Dermatol. 2007;156(6): 1397-1399.

9. Rammeh-Rommani S, Fezaa B, Chelbi E, Kammoun MR, Ben Jilani SB, Zermani R. Syringocystadenoma papilliferum: report of 8 cases. Pathologica. 2006;98(3):178-180.

10. Lin WL, Lin WC, Kuo TT, Chen CH, Hong HS. An unusual complex cutaneous adnexal tumor composed of syringocystadenoma papilliferum, apocrine hidrocystoma, and clear cell syringoma. Dermatol Surg. 2007;33(7):876-879.

11. Shams PN, Hardy TG, El-Bahrawy M, Joshi N. Syringocystadenoma papilliferum of the eyelid in a young girl. Ophthal Plast Reconstr Surg. 2006;22(1):67-69.

12. Kishimoto S, Wakabayashi S, Yamamoto M, Noda Y, Takenaka H, Yasuno H. Apocrine acrosyringeal keratosis in association with syringocystoadenoma papilliferum. Br J Dermatol. 2000;142(3): $543-547$.

13. Yoshii N, Kanekura T, Setoyama M, Kanzaki T. Syringocystadenoma papilliferum: report of the first case on the lower leg. J Dermatol. 2004;31(11):939-942.

14. Philipone E, Chen S. Unique case: syringocystadenoma papilliferum associated with an eccrine nevus. Am J Dermatopathol. 2009;31(8):806-807.

15. Townsend TC, Bowen AR, Nobuhara KK. Syringocystadenoma papilliferum: an unusual cutaneous lesion in a pediatric patient. J Pediatr. 2004;145(1):131-133.

16. Skelton HG 3rd, Smith KJ, Young D, Lupton GP. Condyloma acuminatum associated with syringocystadenoma papilliferum. Am $J$ Dermatopathol. 1994;16(6):628-630.

17. Stewart CJ. Syringocystadenoma papilliferum-like lesion of the vulva. Pathology. 2008;40(6):638-639.

18. Goshima J, Hara H, Okada T, Suzuki H. Syringocystadenoma papilliferum arising on the scrotum. Eur J Dermatol. 2003;13(3):271.

19. Bakshi J, Parida PK. Syringocystadenoma papilliferum: report of first case on the pinna. J Laryngol Otol. 2006;120(12):e45.

20. Askar S, Kilinc N, Aytekin S. Syringocystadenoma papilliferum mimicking basal cell carcinoma on the lower eyelid: a case report. Acta Chir Plast. 2002;44(4):117-119.

21. Barbarino S, McCormick SA, Lauer SA, Milman T. Syringocystadenoma papilliferum of the eyelid. Ophthal Plast Reconstr Surg. 2009; 25(3):185-188.

22. Helmi A, Alaraj AM, Alkatan H. Report of 3 histopathologically documented cases of syringocystadenoma papilliferum involving the eyelid. Can J Ophthalmol. 2011;46(3):287-289.

23. Su TC, Shen KH, Wang HK, Chu PY, Chen ML. Lipomatous apocrine adenoma with syringocystadenoma papilliferum arising from the external auditory canal. Head Neck Oncol. 2011;3:36.

24. Saricaoglu H, Baskan EB, Ozuysal S, Tunali S. A case of syringocystadenoma papilliferum: an unusual localization on postoperative scar. J Eur Acad Dermatol Venereol. 2002;16(5):534-536.

25. Laxmisha C, Thappa DM, Mishra MM, Verma SK. Linear syringocystadenoma papilliferum of the scalp. $J$ Eur Acad Dermatol Venereol. 2007;21(2):275-276.

26. Shindo M, Yamada N, Yoshida Y, Yamamoto O, Morino S. Syringocystadenoma papilliferum on the male nipple. J Dermatol. 2011;38(6):593-596. 
27. Malhotra P, Singh A, Ramesh V. Syringocystadenoma papilliferum on the thigh: an unusual location. Indian J Dermatol Venereol Leprol. 2009;75(2):170-172.

28. Xu XL, Zhang GY, Zeng XS, Wang Q, Sun JF. A case of zonal syringocystadenoma papilliferum of the axilla mimicking verruca vulgaris. Am J Dermatopathol. 2010;32(1):49-51.

29. Ghosh SK, Bandyopadhyay D, Chatterjee G, Bar C. Syringocystadenoma papilliferum: an unusual presentation. Pediatr Dermatol. 2009; 26(6):758-759.

30. Yap FB, Lee BR, Baba R. Syringocystadenoma papilliferum in an unusual location beyond the head and neck region: a case report and review of literature. Dermatol Online J. 2010;16(10):4.

31. Suzuki T, Ikeda H, Hamasaki Y, Hatamochi A, Yamazaki S. Syringocystadenoma papilliferum associated with apocrine poroma. J Dermatol. 2006;33(4):249-251.

32. Shindo K, Hamada T. Syringocystadenoma papilliferum occurred on the lower abdomen. Skin Research. 1991;33(6):660-663. Japanese with abstract in English.
33. Yamamoto O, Doi Y, Hamada T, Hisaoka M, Sasaguri Y. An immunohistochemical and ultrastructural study of syringocystadenoma papilliferum. Br J Dermatol. 2002;147(5):936-945.

34. Aktepe F, Demir Y, Dilek FH. Tubular apocrine adenoma in association with syringocystadenoma papilliferum. Dermatol Online J. 2003;9(1):7.

35. Mazoujian G, Margolis R. Immunohistochemistry of gross cystic disease fluid protein (GCDFP-15) in 65 benign sweat gland tumors of the skin. Am J Dermatopathol. 1988;10(1):28-35.

36. Niizuma K. Syringocystadenoma papilliferum: light and electron microscopic studies. Acta Derm Venereol. 1976;56(5):327-336.

37. Jordan JA, Brown OE, Biavati MJ, Manning SC. Congenital syringocystadenoma papilliferum of the ear and neck treated with the $\mathrm{CO} 2$ laser. Int J Pediatr Otorhinolaryngol. 1996;38(1):81-87.

38. Chi CC, Tsai RY, Wang SH. Syringocystadenocarcinoma papilliferum: successfully treated with Mohs micrographic surgery. Dermatol Surg. 2004;30(3):468-471.
OncoTargets and Therapy

\section{Publish your work in this journal}

OncoTargets and Therapy is an international, peer-reviewed, open access journal focusing on the pathological basis of all cancers, potential targets for therapy and treatment protocols employed to improve the management of cancer patients. The journal also focuses on the impact of management programs and new therapeutic agents and protocols on

\section{Dovepress}

patient perspectives such as quality of life, adherence and satisfaction. The manuscript management system is completely online and includes a very quick and fair peer-review system, which is all easy to use. Visit http://www.dovepress.com/testimonials.php to read real quotes from published authors. 